\title{
Printing the Body of Christ on Fabric
}

\section{Suzanne Karr Schmidt}

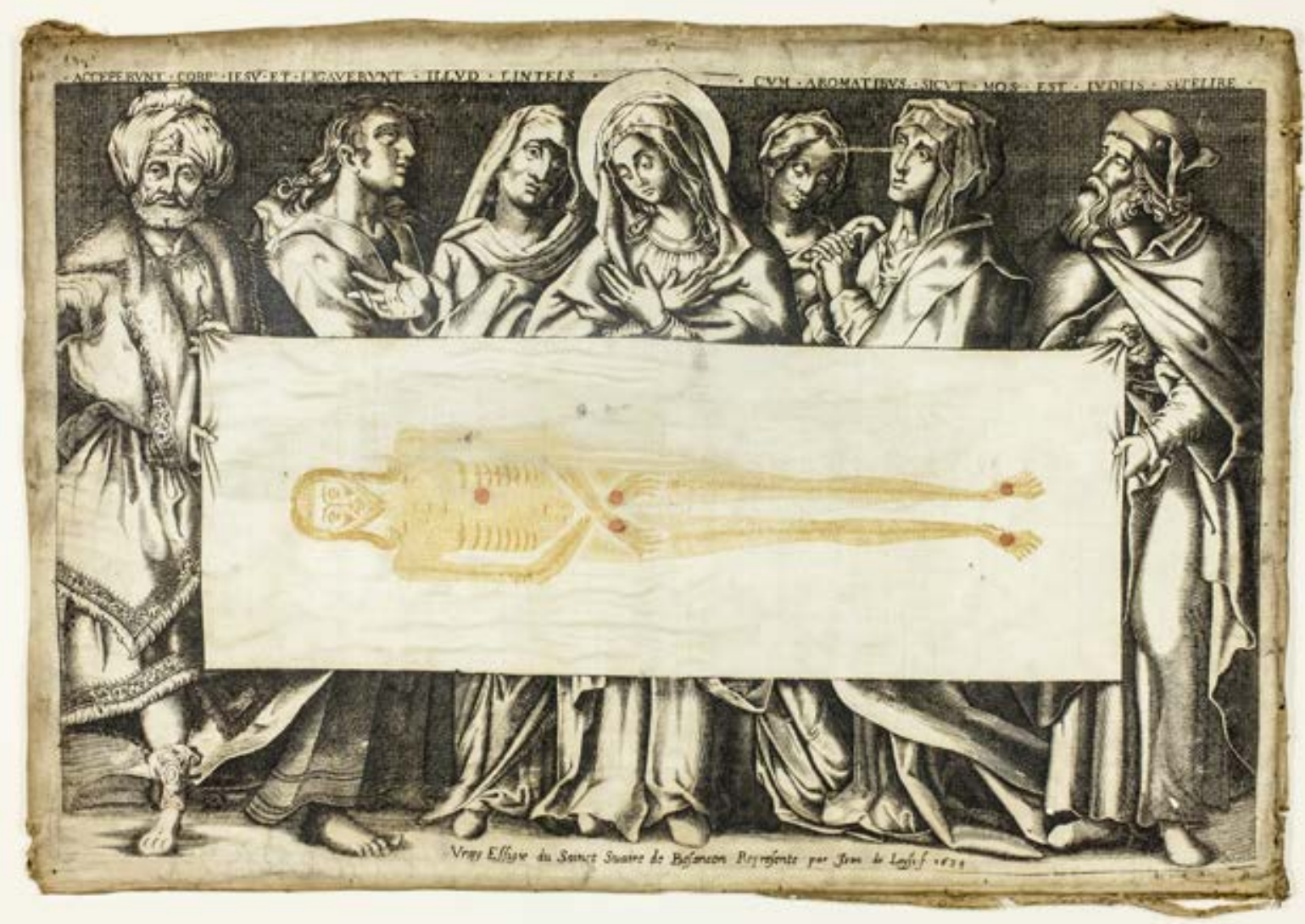

Fig. 1 Jean de Loisy, The Holy Shroud of Besançon, 1634, The Art Institute of Chicago

While most Renaissance and Baroque engravings, etchings, and woodcuts were printed on paper, some extraordinary impressions were produced on silk or linen. A taste for the silver and gold thread of tapestries informed appreciation for shiny silk satin weaves in particular. Contact relics provided a devotional inspiration for the most evocative of these prints on fabric. The most famous contact relics were the Veronica (also known as the Sudarium, Vera Icon, or vernicle) and the Shroud of Turin, which were two distinct relics created, respectively, from direct contact with Christ's face and with his entire body. These initially plain lengths of cloth were said to have been used to wipe Christ's sweat-drenched face as he carried his cross on the way to Calvary (the Veronica) and to wind his body in afterward (the Shroud), leaving traces of his form behind. These relics' first miracle was the ability to transfer their own image and even their power of replication onto other surfaces, thus creating an acheiropoietos, an image made without human hands, a process akin to the art of printmaking itself. ${ }^{1}$

Many woodcuts and engravings of the Veronica survive with illusionistic effects that suggest a fabric support despite being printed on paper. These were often indulgenced images, especially when coupled with the Salve Sancta Facies prayer that was to be 
recited in the honor of the relic and its many replications. ${ }^{2}$ The miraculously transferred power of those relics could be evoked even more powerfully by printing the face or the body of Jesus Christ on actual fabric.

One of the earliest of these is a tiny swatch of loosely woven silk fiber-nearly cheesecloth-like in its porousness - a woodcut design with hand coloring showing just Christ's face. This fifteenth-century work is now in the Albertina in Vienna, which also possesses a similar object printed on leather. The tradition continued, and an exceptional print on fabric from the early seventeenth century now at the Art Institute of Chicago demonstrates the range of devotional uses to which these images printed on unusual supports could be put, from ersatz contact relic, indulgenced object, and pilgrimage souvenir, to a part of liturgical ritual.

This 1634 engraving on cream-colored silk satin was inked in two colors-with a third color added manually-by Jean de Loisy (1603-after 1660), part of a family of goldsmiths, engravers, and mint-managers active in the town of Besançon in SouthEastern France. Their civic claim to fame was the Sainte Suaire, or Holy Shroud, a contact relic the town promoted in direct competition with the Shroud of Turin. Numerous printed representations of the Sainte Suaire in reduced scale appeared throughout the seventeenth century, with many surviving impressions printed on fabric. ${ }^{3}$ In Loisy's Art Institute engraving, Christ's lamenters hold the edge of the creamy white winding sheet, which reveals an abstracted version of his supine form. While the outer area is printed in the standard oil-based black ink that would normally be used on paper, the interior of the reserved rectangular space bears a silhouette in a differently engraved texture printed in yellow ochre-colored ink. It was likely added to the plate using the then still uncommon à la poupée technique (by dabbing different colored inks into the lines with dollies, brushes, stumps, or even fingertips). This internal color change intentionally added a separate step to achieve the desired effect of verisimilitude to the original relic. The final details of the welling blood near the heart and on the hands and feet were added separately by hand, either on the plate or to the subsequent print. The effect of the localized color is striking, as if the shroud in the center of the composition were real, re-impressed in color onto the silken sheet.

Another impression on a silk satin woven fabric, at the Bibliothèque nationale de France, loses some of the visual impact because it is printed only in black and white, making the sheet a more continuous field that focuses less on this engraved shroud's resemblance to the original. The monochromatic impression gains additional dimensionality in that the holes for the wounds were either punched to give the appearance of depth, or the central figure consisted of a separately engraved plate nailed onto the main one. The location of these holes-through the hand and foot nail wounds-also offered further resonance with the nails that affixed Christ to the cross. While the plate that produced the Art Institute impression lacks this detail, Loisy achieved a stronger effect by creating the ghostly shade of the body by means of dotting, the silhouetted figure further inked in yellow ochre, with the nail wounds touched manually with red paint. ${ }^{4}$ 


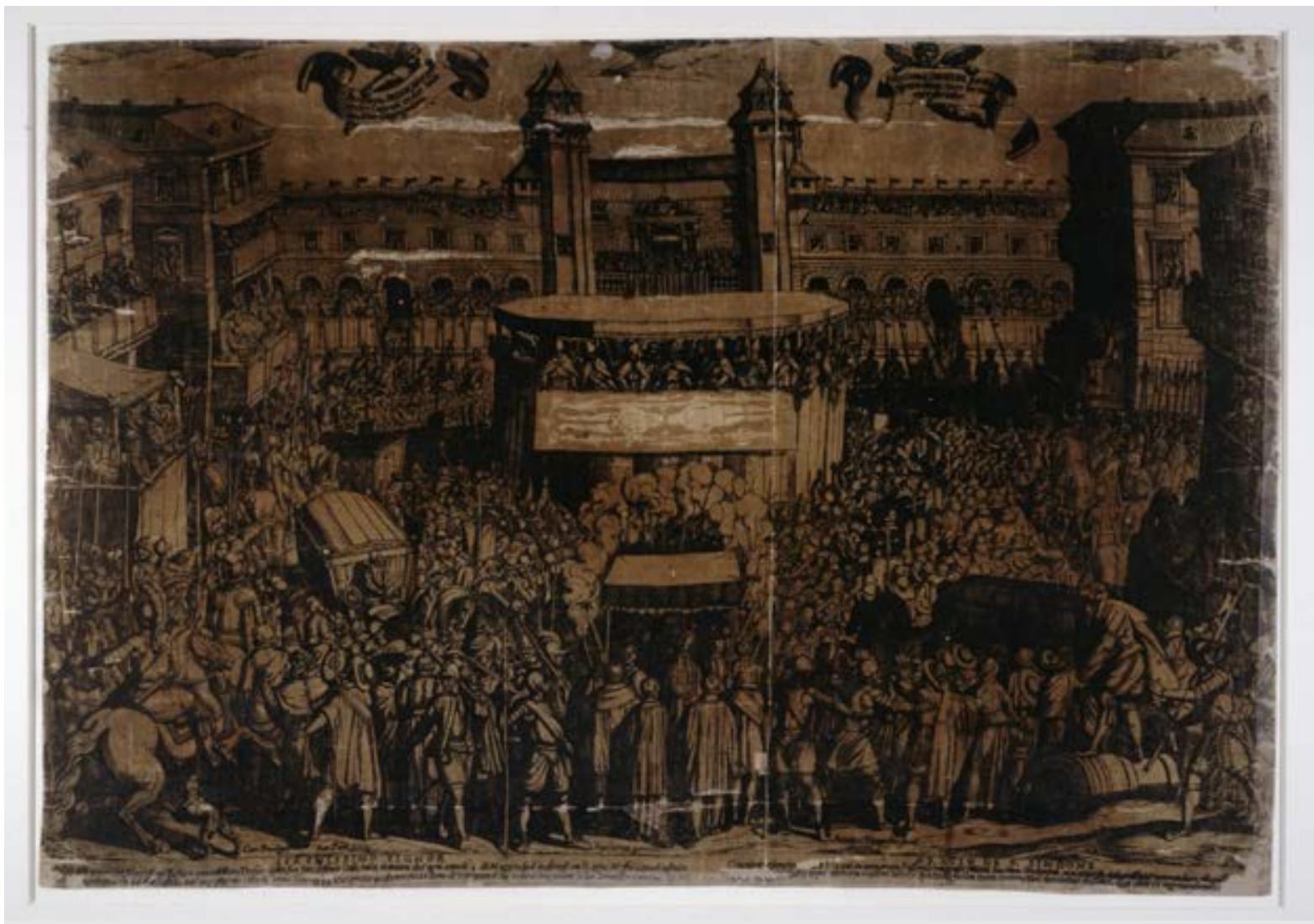

Fig. 2 Antonio Tempesta, The annual display of the Holy Shroud in Turin on 4 May. After 1593, etching and woodcut printed on silk. 426 x 620 mm. The British Museum, 1862,0712.502. Photograph (C) Trustees of the British Museum

Jean de Loisy looked to other printed models, using Caspar, one of the Lorraine-based artist Jacques Bellange (1575-1616)'s Three Magi as the leftmost figure (likely depicting Joseph of Arimathea) in his Holy Shroud. Given the wider cultural awareness Loisy's use of the Bellange print attests to, Loisy might also have encountered another print on fabric of a different holy shroud. The Italian artist Antonio Tempesta (c. 1555-1630) had produced a similar print on fabric around 1600, an etching in black with a brown tone printed from a woodblock, a complex image printed at least once on a sheet of silk taffeta, now in the British Museum. Unlike the Loisy, Tempesta puts his image of the shroud on festival display with the impression of the body appearing in negative where the woodblock was cut away, these white highlights forming the compositional center of attention. Loisy in contrast focuses on the shroud in the moment of its first contact with Christ during the Deposition. Joseph of Arimathea and Nicodemus hoist the ends of the fabric, lifting it to the viewer as if they too are taking part in a relic showing. The Virgin Mary, the Magdalene, and John the Evangelist all look on in abject mourning. The engraved folds at the corners and the slight undulations of the fabric in the central void of the Art Institute impression give the sense of the shifting of the body's weight, while simultaneously referring to the actual contact relic in the Besançon cathedral. The text below the 1634 Loisy image in fact notes that this is a "vrai effigie," or "true likeness" of the Sainte Suaire de Bensançon, assuring potential buyers of its authenticity. While Jean de Loisy never included the oraison prayer that was dedicated to the holy shroud 
in Besançon (like the Salve Sancta Facies for the Veronica), later shrouds printed in his family from 1658 onward specified both the prayer and the indulgence that Clement VIII afforded images of the body of Christ. Dwelling on the "marks of [his] passion" left when Joseph of Arimathea enveloped Christ's body in the winding sheet gave the devotee the ability to release one soul from Purgatory per recitation of the prayer in the presence of an image of the Holy Shroud. ${ }^{5}$

The actual provenance of the relic and whether it indeed came from the Holy Land remains in dispute, with the simplest explanation being that it may have been copied after one half of the double impression on the Turin Shroud. Nonetheless, the Besançon cult became increasingly famous (and so in need of commercial replication) in the second half of the sixteenth century, especially after Pope Gregory XIII privileged the altar of the holy shroud in 1579. On August 15, 1599 the city decided to restrict private access to the relic to "kings, dukes, and princes of royal blood," but had to reverse their decision only six months later due to a marked decline in related donations. The acuteness of the demand to see the Sainte Suaire, sometimes with visitation totaling over 30,000 pilgrims on the Easter Sunday viewings into the seventeenth century, is attested by the number and variety of prints produced by Loisy and his family. While only a handful of impressions of the Art Institute's specific image are known, others were printed from a nearly identical plate produced around the same time, with both dated 1634, and tellingly, all of them printed exclusively on fabric. ${ }^{6}$

Several international noble visitors over the spring and summer of 1634 who enjoyed private viewings - and might have been given or purchased impressions of the Loisy print-included the Marquis de Bade (April 21), the Maréchal de Bassompierre (an officer of the Duke of Lorraine, in July), and the Countess of Nassau, in August.7 During that year and those immediately following, demand increased for the prints, as the metropolitan chapter of the city sent five images of the Saint Suaire to the town of Dolois (now Dole, about 30 miles away) to combat the plague on November 19, 1636. Four were posted at the corners of the village, and the fifth in its center. ${ }^{8}$ Perhaps these were the very same shrouds printed by Jean de Loisy in 1634. The aforementioned Maréchal de Bassompierre became a frequent visitor, returning again on April 30, 1637 when the Saint Suaire was carried in a procession in honor of the "success of the imperial forces." 9 Two years later his superior, the Duke of Lorraine, had two of his heraldic banners hung in the chapel as well as commissioning a life-size copy of the 8-foot shroud for the German Emperor, apparently the only individual with the right to own one in exact scale.

Jean de Loisy's brother, Pierre II de Loisy, received a 1658 privilege to produce at least two smaller, but official representations of the shroud, and continued using the subject even into the 1660 s. $^{10}$ This would prove forward thinking as in 1669 the Sainte Suaire was translated from the soon-to be demolished cathedral of Saint Etienne to the cathedral of Saint-Jean, also in Besançon, an important occasion for the commemoration of any major relic. Pierre II's larger-scale version (about $15 \mathrm{~cm}$ larger in each direction), which also received a privilege in 1669, repeated Jean's composition and, more importantly, the production method, using a more textured fabric, but 
maintaining the three-part color scheme that set the first version apart. Other versions followed with different saints beholding the shroud, its abstract central design usually colored and set off by a white background. The many printed reproductions of the shroud from the Loisy family and others date into the late eighteenth-century, some forty of which survive at the Archives départmentales du Doubs (Besançon) alone. Adding to the resonance of the fabric with images of the contact relics they conjure up, they could have been intended for private use in the flickering light of a candlelit family chapel (or personal meditation at home). A print on paper would have been appropriate for album or wall display, and so could a fabric print be mounted, framed, or hung on rollers.

In addition to replicating the materiality of the original object, silk had a further benefit over paper-it flowed. In perhaps the most evocative presentation of all, the prints could have been draped protectively over the Eucharistic chalice and host-bearing paten during the first part of Mass, becoming a double evocation of the body and blood of Christ that would fill these receptacles during the Eucharist. These linen or silk covers were also known as chalice veils or, in more funereal terms, as palls, and the vessels they protected from dust and other contaminants would be unveiled only when the sacrament had commenced. ${ }^{11}$ Chalice veils frequently consisted of square panels with a wide lace border and a reserved area of plain fabric in the center to rest on top of the chalice. $^{12}$

Multiples printed on silk in shiny satin or taffeta weaves offered a simultaneously luxurious and cost-effective version of these plain square or rectangular lace-framed pieces of ritual fabric. Printmakers could reproduce the appearance of lace without the labor involved in making or importing the actual material, but they could also augment the plain fabric center with a sacred scene. Spectacular seventeenth-century engravings of this type include an anonymous satin Last Supper chalice cloth fringed with fictive Italianate lace and a monochrome altar cloth showing the Crucifixion printed on linen by Magdalene de Passe that boasts sizable scalloped "lace" panels around the exterior. Every Holy Shroud by the Loisy family incorporated a prominently vacant central area comparable to the blank area reserved on chalice veils to cover the opening of the vessel, only to imprint it with the Body of Christ himself, his bleeding wounds on display for all to see. Nothing could be a more fitting cover for the chalice that would soon hold some of that consecrated wine. Jean de Loisy's engraved border, filled as it is with the many pious enactors of the Deposition, is not a design meant to represent a traditional piece of lace, but it sets off its central holy burden just as effectively.

As so many copies of the original Saint Suaire relic were needed during these troubled times of disease and conflict going into the Thirty Years War, the Loisy family, and Besançon more broadly, capitalized inventively on their most famous export. Now the Loisy prints are almost all that is left. All eight by four feet of the linen comprising the original Sainte Suaire relic was torn up on May 24, 1794 and used as bandages for the French revolutionaries. What survives is the legacy of the Loisy prints on fabric. By sensitively using this technique, they multiplied the relic's form, extended its availability to the faithful, and miraculously increased its fame. 
(C) Suzanne Karr Schmidt

\section{Citation Guide}

1. Suzanne Karr Schmidt, "Printing the Body of Christ on Fabric," Medium Study, in Conversations: An Online Journal of the Center for the Study of Material and Visual Cultures of Religion (2016), doi:10.22332/con.mst.2016.1

Schmidt, Suzanne Karr. "Printing the Body of Christ on Fabric." Medium Study. In Conversations: An Online Journal of the Center for the Study of Material and Visual Cultures of Religion (2016). doi:10.22332/con.mst.2016.1

\section{Notes}

1. A classic study engaging with the Veronica, Vera Icon, and the archeiopoetos is Joseph Koerner, The Moment of Self-Portraiture in German Renaissance Art. (Chicago: University of Chicago Press, 1993). For a fascinating recent article on the recreation of a Veronica image through woodcuts, see Nicole Blackwood, "Printmaker as Painter: Looking Closely at Ugo da Carpi's Veronica Altarpiece," Oxford Art Journal (2013) 36 (2): 167-184.

2. Suzanne Karr Schmidt, "Marginal Devotions: A Newly Acquired Veronica Woodcut," Yale University Art Gallery Bulletin (2002), 99-104.

3. An album in the Réserve of the Bibliothèque nationale de France ( $\left.\mathrm{RC}_{3} 6 \mathrm{r}\right)$ contains examples of the Sainte Suaire on fabric by Jean de Loisy and Germain Bourrelier; while the Archives départementales du Doubs, much of which is viewable online, includes some twenty variants by the Loisy family

4. On ghostly stippled outlines in this period, see Ad Stijnman, A History of Engraving and Etching Techniques: Developments of Manual Intaglio Printmaking Processes, 1400-200O, (London: Archetype; ‘t Goy-Houten: Hes \& De Graaf, 2012), 182, 209. Many thanks are due directly to Ad Stijnman for his insightful comments on this essay, and his enthusiasm for the Chicago Loisy engraving as a technically complicated and important early color print.

5. Oraison au S. Suaire. O Dieu qui dans le Sainct Suire au quel vostre tres sacré corps estant oste de la Croix fut enveloppé par Joseph avez laisez les marques de vostre passion concedé misericordieusement que par vostre mort et spulture nous puission arriver a la gloire de la resurrection qui vivez et regnez avec dieu le pére en unité du Sainct Esprit Amen. Le Pape Clement 8 a concede que lors qu'on dira ladite oraison on delivre une ame du purgatoire.

6. Known impressions of the 1634 Jean de Loisy sheet include: Art Institute of Chicago 
(2013.162, color, plate 1); Association Trésors de Ferveur (color, plate 1, poor condition); Réserve, Bibliothèque nationale de France (black and white, plate 2); Archives départmentales du Doubs (color, plate 2)

7. Jean-Marie Thiébaud, "Le Saint-Suaire de Besancon," L'Harmattan, 2006. http://www.editions-harmattan.fr/index. asp?navig $=$ catalogue\&obj=article\&no $=3499 \&$ razSqlClone $=1$ Includes a list of notable visitors and copious archival notes about the relic.

8. Thiébaud 2006.

9. Thiébaud 2006.

10. Remi Mathis, A Kingdom of Images: French Prints in the Age of Louis XIV, 166o1715 (Getty Research Institute, Los Angeles, 2015), 227.

11. G. Thomas Ryan, The Sacristy Manual (Archdiocese of Chicago: Liturgy Training Publications, 1993), 142.

12. The Last Supper (Anonymous after Livio Agresti, The Last Supper, engraving printed on linen, 47 x $48.5 \mathrm{~cm}$. Manchester, Metropolitan University, Textiles/Fashion Archives inv. 21) appears in Jan van der Waals, Prenten in de Gouden Eeuw van kunst tot kastpapier (Rotterdam: Museum Boijmans van Beuningen, 2006), 92-93; and the altar cloth (Magdalena de Passe, Crucifixion, engraving printed on linen. 53 x 53 cm. Olivone, Museo di San Martino), Thea Tibiletti, "Magdalena de Pas $<<$ sculptrix celeberrima >>," in Quaderni bleniesi, (Olivione: Fondazione Jacob-Piazza, 1997), 8-15. 